\title{
Comparative biology and functional response of Trissolcus spp. (Hymenoptera: Scelionidae) and implications for stink bugs (Hemiptera: Pentatomidae) biological control
}

\author{
R.A. Laumann ${ }^{\mathrm{a}, \mathrm{b}, *}$, M.C.B. Moraes ${ }^{\mathrm{a}}$, M. Pareja ${ }^{\mathrm{a}}$, G.C. Alarcão ${ }^{\mathrm{b}}$, A.C. Botelho ${ }^{\mathrm{b}}$, \\ A.H.N. Maia ${ }^{\text {c }}$, E. Leonardecz ${ }^{\text {d }}$, M. Borges ${ }^{a}$ \\ ${ }^{a}$ Núcleo Temático de Controle Biológico, Embrapa Recursos Genéticos e Biotecnologia, Brasília, DF, Brazil

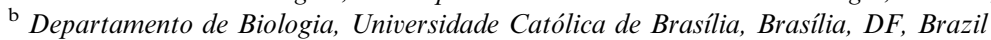 \\ ${ }^{\mathrm{c}}$ Laboratório de Geotecnolgias e Métodos Quantitativos, Embrapa Meio Ambiente, São Paulo, SP, Brazil \\ d Programa em Ciências Genómicas e Biotecnologia, Universidade Católica de Brasília, DF, Brazil
}

Received 5 April 2007; accepted 4 October 2007

Available online 12 October 2007

\begin{abstract}
The biological parameters and functional responses of populations of Trissolcus basalis, Trissolcus brochymenae, Trissolcus teretis and Trissolcus urichi, from central Brazil, attacking Euschistus heros eggs were studied, in order to establish their potential for stink bug biological control. Life table analyses and functional response experiments were used to evaluate and analyze the performance of species when using E. heros eggs as host. There was substantial variation in the ability of different Trissolcus spp. to exploit resources from E. heros eggs. Fecundity measures of Trissolcus spp. when compared to that of E. heros showed that the parasitoids have potential for faster population increase than the stink bug. The four species studied showed type III functional responses. The species of Trissolcus evaluated in this work are potentially effective as natural enemies of E. heros, and can potentially be used in a multi-species approach. Interference competition and other ecological and behavioral effects of more complex environments can occur, as in multiple-species introductions or when alternative hosts are present.
\end{abstract}

(C) 2007 Elsevier Inc. All rights reserved.

Keywords: Trissolcus basalis; Trissolcus brochymenae; Trissolcus teretis; Trissolcus urichi; Euschistus heros; Multi-species use; Density-dependence; Life table parameters

\section{Introduction}

Stink bugs (Hemiptera: Pentatomidae) are major pests of soybean and other crops in several countries around the world (Panizzi, 1997). For soybean, stink bugs cause damage during their reproductive stages (Panizzi, 1997), in a direct manner by sucking pods and grains, and indirectly through fungal transmission and physiological alterations (Villas-Bôas et al., 1990; Sosa-Gómez and Moscardi,

\footnotetext{
* Corresponding author. Address: Núcleo Temático de Controle Biológico, Embrapa Recursos Genéticos e Biotecnologia, Brasília, DF, Brazil. Fax: +556134484673 .

E-mail address: laumann@cenargen.embrapa.br (R.A. Laumann).
}

1995; Boethel et al., 2000). In central Brazil, especially Distrito Federal, seven species of stink bugs have been associated with soybean (Sujii et al., 2002). In this species complex, the brown stink bug, Euschistus heros (Fabricius, 1798 ) is the key pest due to its abundance and serious damage to the crop (Panizzi and Slansky, 1985; Panizzi and Corrêa-Ferreira, 1997; Medeiros et al., 1997).

Egg parasitoids (Scelionidae) are important natural enemies of stink bugs (Panizzi and Slansky, 1985; CorrêaFerreira and Moscardi, 1995 and references therein). Some species of this family have been considered and used in many countries for biological control of stink bugs, especially the cosmopolitan Trissolcus basalis (Wollaston, 1958) and Telenomus podisi Ashmead, 1881 (Caltagirone, 
1981; Clarke, 1990; Corrêa-Ferreira, 2002). T. basalis has a long history of research as a natural enemy and biological control agent of the southern green stink bug, Nezara viridula (L., 1758) in several countries (Cumber, 1951; Crouzel and Saini, 1983; Clarke, 1990; Clarke and Walter, 1995; Colazza and Bin, 1995; Ehler, 2002; Hoffmann et al., 1991; Johnson et al., 2005), with satisfactory to outstanding control of the stink bug in some countries (Caltagirone, 1981; Ehler, 2002), but dubious results in others (Clarke, 1990; Ehler, 2002). In Brazil, Corrêa-Ferreira and Moscardi (1996) showed that inoculative liberation of $T$. basalis can control populations of stink bugs, and this technology is being applied in micro-basin production systems in Southern Brazil (Corrêa-Ferreira, 2002). In central Brazil, $E$. heros shows high natural parasitism indices that can reach 60-80\% (Kobayashi and Cosenza, 1987; Medeiros et al., 1997, 1998). Four species of Trissolcus (T. basalis, T. brochymenae (Ashmead, 1881) T. teretis (Johnson, 1987) and T. urichi (Crawford, 1913)) were reported as egg parasitoids of $E$. heros (Medeiros et al., 1998).

Despite several studies related to incidence and parasitism indices (Kobayashi and Cosenza, 1987; Medeiros et al., 1997, 1998), behavior (Borges et al. 1999; Sujii et al, 2002) and chemical ecology (Borges et al., 2003; Moraes et al., 2005; Cavalcante et al., 2006) of the species occurring in central Brazil, population biology of the Trissolcus spp. cited above when developing on E. heros is practically unknown, and for T. teretis and T. urichi it has never been reported.

The objectives in this study were: (1) to establish demographic parameters of $T$. basalis, $T$. brochymenae, $T$. teretis and $T$. urichi when using E. heros eggs as hosts and (2) to compare the types of functional responses and their parameters between species, when the species foraged in a single patch. The results from this study will contribute towards understanding the population biology of scelionid parasitoids, and establishing which of these species are potential biological control agents of stink bugs. Additionally, understanding the response of parasitoids to host density (functional response) is crucial for the implementation of rapid population control required in inundative biological control systems (Mills and Lacan, 2004). Parasitoids with type III (sigmoidal) functional responses will have greater ability to cause density-dependent parasitism, thus reducing the pest population in patches where it is growing most, and increasing the potential for local-scale population regulation. Furthermore measuring functional responses of parasitoids being used in biological control, and relating this to population suppression, can help in the development of predictive biological control models (Mills, 2001).

\section{Materials and methods}

\subsection{Insects}

Colonies were started from insects collected on soybean and natural areas of Distrito Federal (Brazil), near Brasília $\left(15^{\circ} 47^{\prime} \mathrm{S}\right.$ and $\left.47^{\circ} 55^{\prime} \mathrm{W}\right)$. Voucher specimens were deposited in the insect collection of Embrapa Genetic Resources and Biotechnology.

The parasitoids were maintained in an environmental chamber in plastic cages (tissue culture $25 \mathrm{~cm}^{2}$ flask, angled neck-ICN Biomedicals, Irvine, CA). Host (E. heros) eggs, glued with arabic glue on card strips $(5 \times 1 \mathrm{~cm})$ were exposed to parasitoids for $24 \mathrm{~h}$ and then removed and placed in glass tubes $(7.5 \mathrm{~cm}$ long $\times 1.3 \mathrm{~cm}$ diameter $)$ for incubation. Droplets of honey were offered to adult parasitoids as food.

Euschistus heros was reared on sunflower (Helianthus annuus (L.)), soybean (Glycine max (L.) Merrill.), raw peanut (Arachis hypogaea (L.)) seeds and green beans (Phaseolus vulgaris (L.)). Separate 81 plastic containers were used for nymphs and adults. The eggs were collected daily and separated in Petri dishes until nymphal eclosion. Both $E$. heros and parasitoids were reared under $14 \mathrm{~h}$ photophase at $26.0 \pm 1{ }^{\circ} \mathrm{C}$ and $65 \pm 10 \%$ relative humidity.

\subsection{Parasitoid biology}

Life table analyses were used for the studies and estimation of biological parameters. All experiments were conducted at the same environmental conditions described above.

To estimate development time and survivorship of immature stages, $50 \mathrm{E}$. heros eggs were offered, glued on card strips, to four females for $24 \mathrm{~h}$. The females used were 24-48 h old and previously maintained with males to mate. Five to eight replicates were performed for each species. After this period the egg masses were placed into glass tubes $(7.5 \mathrm{~cm}$ long $\times 1 \mathrm{~cm}$ diameter) and maintained under rearing conditions until adult emergence. Every morning egg masses were observed in order to evaluate (1) developmental time, which was measured as the time in days between when eggs were offered to females and adult parasitoid emergence and (2) mortality of immature stages, calculated using the ratio of adults emerging to eggs originally parasitized, estimated by color change (Medeiros et al., 1997). When egg color did not offer a clear indication and the parasitoid did not complete its development, the eggs were dissected under stereoscopic microscopy in order to confirm parasitism.

Adults obtained from parasitized eggs were used to form male-female couples ( $n=20$ for each species). These couples were maintained individually in glass tubes $(7.5 \times 1 \mathrm{~cm})$ and fed with bee honey until adults died. Masses of $E$. heros eggs ( $n=30$ per mass), glued on card strips, were offered to each female daily. Egg masses (of each day) were identified with date, species and female to which they were exposed, and maintained in the rearing chamber in glass tubes until adult emergence. Survivorship of females, number of egg masses parasitized (number of egg masses with at least one egg parasitized), total fecundity (estimated by number of eggs parasitized/female) were evaluated. In addition, the influence of female age on 
reproductive parameters (proportion of parasitized eggs, immature survivorship and sex ratio of offspring) was evaluated. Female age ( $x$ : estimated from development time of larvae +0.5 days), daily fertility ( $m_{x}$ : number of females/ female in each day) and female survivorship ( $l_{x}$ : proportion of females surviving in each day) were computed.

\subsection{Functional response studies}

Females of each species of parasitoid $(<24 \mathrm{~h}$ after molt) were maintained with males for a $24 \mathrm{~h}$ period. After this they were individually and randomly introduced into glass tubes $(7.5 \mathrm{~cm}$ long $\times 1 \mathrm{~cm}$ diameter) containing $E$. heros eggs, glued on card strips. For each female a density of either 1, 2, 4, 8, 16, 32, 37, 45 or 64 eggs was offered. Five replicates per density were performed and the parasitoid females were maintained in the glass tube for $6 \mathrm{~h}$ in order to evaluate response to egg densities and avoid effects of female egg depletion. After this period egg masses were removed and maintained in a rearing room. The number of parasitized eggs, evaluated with the same methodologies and criteria described above (parasitoid biology), were used to calculate the proportion of parasitized eggs at each density. Environmental conditions for the experiments were the same as described in the insect rearing methodology.

\subsection{Data analyses}

The mean percentages of immature stage survivorship of each species were compared using ANOVA and StudentNewman-Keuls (SNK) test for multiple mean comparisons. Mean development time of immature stages was compared using Kruskal-Wallis and SNK tests. Survivorship curves of females were compared with Kaplan-Meier Survival Analysis, i.e. Log-rank test and Holm-Sidak method for pairwise multiple comparisons. Mean number of egg masses parasitized by each species were compared using Kruskal-Wallis test and mean number of eggs parasitized/female were compared using ANOVA and SNK test.

Female age, survivorship and specific fecundity data were used to estimate mean and standard deviation of fecundity table parameters using the computer program LIFETABLE.SAS, developed by Maia et al. (2000), using functions and procedures of the SAS System for Windows (SAS Institute, 1990). This program uses the Jackknife technique to estimate life table parameters. In this work, net reproductive rate (Ro: female progeny/female), intrinsic rate of population increase $\left(r_{\mathrm{m}}\right.$ : instantaneous production of female progeny/female), mean generation time ( $T$ : mean age of females at birth of first female progeny) and finite rate of population increase ( $\lambda$ : female progeny/ female/day) were estimated. Life table parameters were compared by $t$ tests for contrasts, using jackknife estimates of their respective variances.

Data from functional response experiments were used to establish the type and parameters of functional response using the approach developed by Juliano (1993). This approach includes two sequential analyses. Initially, the type of functional response is established using a polynomial logistic regression of proportion of prey/host eaten/ parasitized $\left(N_{\mathrm{p}} / N_{\mathrm{o}}\right)$ vs. number of prey/host offered $\left(N_{\mathrm{o}}\right)$. The curves of $N_{\mathrm{p}} / N_{\mathrm{o}}$ vs. $N_{\mathrm{o}}$ when the response is a Type II, have the shape of a negative exponential (proportion of parasitized decaying exponentially) and when the response is a Type III have a dome-shape, with a maximal of proportion parasitized and then a continuous decline. These curves may both be fit by quadratic (or higher order) polynomials expressions. In the Type II curves the linear $(P 1$ in Eq. (1)) and quadratic ( $P 2$ in the Eq. (1)) term would be negative (initially decreasing) whereas in the Type III curve the linear term would be positive (initially increasing) and the quadratic term negative (Trexler et al., 1988; Juliano, 1993). Thus, one criterion for separating type II and III functional responses by analyzing proportion of prey eaten is to test for significant positive or negative linear coefficients in the expression fit by the method of maximum likelihood to data of proportion eaten vs. $N_{\mathrm{o}}$. The second part of the analyses uses a non linear least squares method to obtain estimates of the functional response parameters (Juliano, 1993).

Relationships between proportion of eggs parasitized and density of eggs offered were used, initially, to perform logistic regression (CATMOD procedure for SAS), using the polynomial function:

$\frac{N_{\mathrm{p}}}{N_{0}}=\frac{\exp \left(P_{0}+P_{1} N_{0}+P_{2} N_{0}^{2}+P_{3} N_{0}^{3}+\ldots+P_{Z} N_{0}^{Z}\right)}{1+\exp \left(P_{0}+P_{1} N_{0}+P_{2} N_{0}^{2}+P_{3} N_{0}^{3}+\ldots+P_{Z} N_{0}^{Z}\right)}$

where $N_{\mathrm{p}}$ is the number of egg parasitized, $N_{0}$ is the initial egg density and $P_{0}, P_{1}, P_{2}, P_{3}, P_{z}$ are the parameters to be estimated by maximum likelihood. As in many cases a cubic or higher order expression are necessaries for good fits, we use, in each data set, the expression that better adjusts to the data (cubic for $T$. basalis, $T$. brochymenae and $T$. teretis and a five order expression for T. urichi).

All the data set adjust for a Type III, functional response them. After this analysis parameters of functional response were estimated using:

$N_{\mathrm{p}}=N_{0}\left\{1-\exp \left[\left(d+b N_{0}\right)\left(T_{\mathrm{h}} N_{\mathrm{p}}-T\right) /\left(1+c N_{0}\right)\right]\right\}$

where the constants $b, c$ and $d$ relate the attack coefficient and $T_{\mathrm{h}}$ is the handling time and $T$ the total time available for parasitism $(6 \mathrm{~h})$, and which accounts for type III functional responses with host depletion (Rogers, 1972; Juliano, 1993), which assumes recognition of parasitized eggs, and hence little or no superparasitism.

For all data sets (species) the criteria from Juliano (1993) for simplifying the model were met, thus Eq. (2) was reduced to the following expression:

$N_{\mathrm{p}}=N_{0}\left\{1-\exp \left[\left(b N_{0}\right)\left(T_{\mathrm{h}} N_{\mathrm{p}}-T\right)\right]\right\}$

The parameters of functional response $b$ (attack coefficient) and $T_{\mathrm{h}}$ (handling time) were estimated by performing a non 
linear least squares regression (NLIN procedure of SAS). This method is iterative and requires initial estimates of the parameters that were set using the recommendations from Juliano (1993). Significant differences between parameters of the species were tested with the superposition of $95 \%$ confidence intervals criterion. Mean values of $T_{\mathrm{h}}$, estimated by non linear least squares regression, were used to calculate maximum attack rate as $T / T_{\mathrm{h}}$ (Hassel, 2000), that represent the maximal number of eggs that can be parasitized by a female during the time interval considered.

\section{Results}

\subsection{Parasitoid biology}

Trissolcus basalis showed a better performance in E. heros eggs than did T. brochymenae, T. teretis and T. urichi, whose immature survivorship was $50 \%$ or less (ANOVA $F_{3,28}=7.56, P<0.001$, SNK test $P<0.05$ ) (Table 1). T. basalis also showed the longest mean development time of its immature stage (Kruskal-Wallis test $H=378.58$, $\mathrm{gl}=3, P<0.001$, SNK test $P<0.05$ ) (Table 1), and T. urichi, developed faster than the other species (Table 1).

Mean adult longevity was influenced by species $\left(F_{3,152}=11.94 P<0.001\right), \operatorname{sex}\left(F_{1,152}=7.32, P=0.008\right)$ and the interaction between these factors $\left(F_{3,152}=5.79\right.$, $P<0.001)$. Mean female longevity was longer than that of males, with the exception of T. urichi, but only in T. teretis was this difference significant. Survivorship curves showed the same pattern for Trissolcus spp. and the statistical differences between the curves were significant. T. basalis and T. brochymenane did not show statistically significant differences between survivorship curves (Kaplan-Meier Survival Analysis Log-rank test $S=49.25$, $\mathrm{df}=3, \quad P<0.001$ and pairwise multiple comparisons Holm-Sidak method $P=0.05$ ) (Fig. 1). T. teretis showed the highest survivorship, agreeing with its higher mean longevity (data not shown).

The mean number of egg masses parasitized per female did not differ significantly among species (Kruskal-Wallis test $H=17.52$, df $=14, P=0.23$ ) (Fig. 2A). On the other hand, female fecundity (mean number of host eggs parasitized/female) was higher in $T$. basalis than in the others species (ANOVA $F_{3,76}=7.04, \quad P<0.001$ and $\mathrm{SNK}$ test $P=0.05)$ (Fig. 2B). This result was similar for specific

Table 1

Mean survivorship and development time \pm SD of immature stages of four species of Trissolcus reared on Euschistus heros eggs

\begin{tabular}{llc}
\hline Species & Surivorship (\%) & Development time (days) \\
\hline Trissolcus basalis & $75.17 \pm 9.04 \mathrm{a}$ & $11.40 \pm 0.78 \mathrm{a}$ \\
Trissolcus brochymenae & $55.38 \pm 14.13 \mathrm{~b}$ & $9.76 \pm 0.75 \mathrm{~b}$ \\
Trissolcus teretis & $49.00 \pm 6.68 \mathrm{~b} \mathrm{c}$ & $9.71 \pm 0.74 \mathrm{~b}$ \\
Trissolcus urichi & $38.44 \pm 20.05 \mathrm{c}$ & $8.47 \pm 0.86 \mathrm{c}$
\end{tabular}

Mean in each column followed by the same letter are not significantly different (SNK test, $P>0.05$ ).

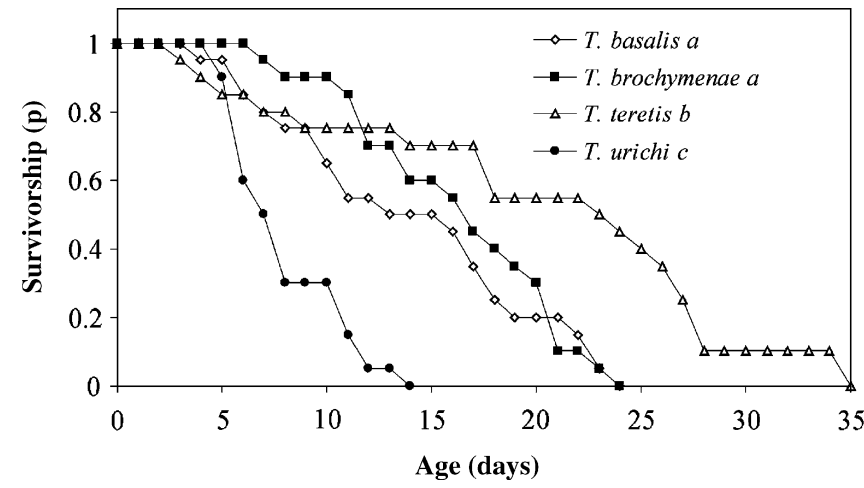

Fig. 1. Estimated survivorship (proportion of initial number) of Trissolcus spp. females developing on E. heros as host. Species ticks followed by different letter indicate significant differences between survivorship curves (Log-Rank Test, and Holm-Sidak method for pairwise multiple comparison $P<0.05)$.
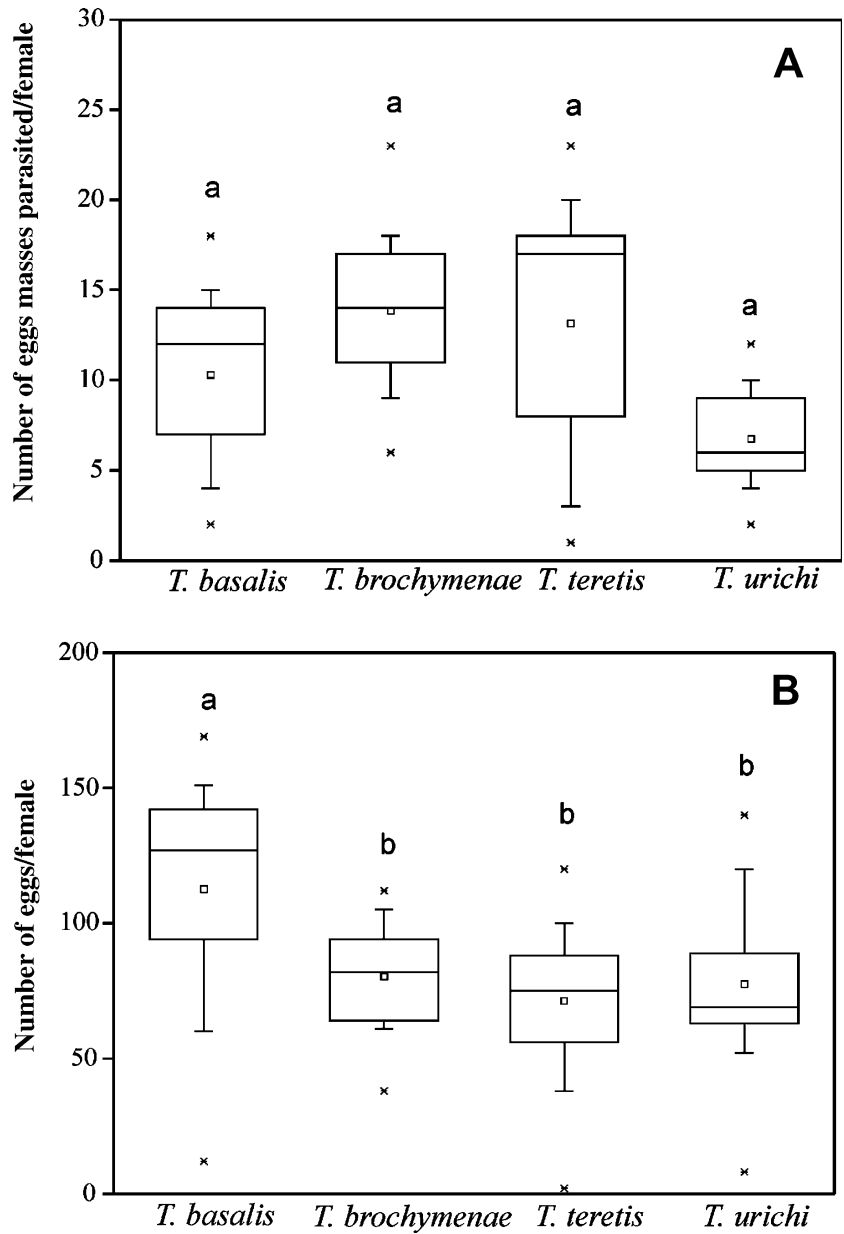

Fig. 2. Box plots of (A) number of egg masses parasitized and (B) fecundity (eggs per female) for Trissolcus spp. on Euschistus heros eggs. Box indicate percentiles (25-75\%), horizontal line in the box indicates median value, square in the box mean value, vertical lines indicate minimum and maximum values at distances $\leqslant 1.5 \times$ from distance between percentiles and stars out of box indicate the maximal and minimal values observed in the group. Box for each species with the same letters above indicate differences between mean values that are not statistically significant (ANOVA and SNK test $P<0.05$ ). 
fecundity (Ro, females/female) calculated from fecundity tables, that was significantly higher for $T$. basalis than the other species (Table 2). In contrast, intrinsic rate of increase $\left(r_{\mathrm{m}}\right)$, and finite rate of increase $(\lambda)$ showed higher values for $T$. brochymenae and $T$. urichi in comparison to $T$. basalis and $T$. teretis (Table 2). Finally, generation time ( $T$ ) was shorter for $T$. urichi (Table 2), influenced by the shorter development time of this species that reduced the initial reproductive age of females.

In the four species of Trissolcus studied, the age of females showed the same effect on reproductive parameters. Mean proportion of parasitized eggs and immature survivorship showed a continuous reduction with female age (Fig. 3a and b) showing a clear effect of age in the production and viability of the eggs. There was also a reduction in the proportion of females in the progeny, suggesting there was sperm depletion (Fig. 3c). This effect is more clearly observed in $T$. teretis, in this species proportion of females in progeny fall below 0.2 after 5 days (Fig. 3c).

\subsection{Functional response studies}

Host density, parasitoid species and the interaction between these factors showed significant effects on the number E. heros eggs parasitized (Table 3). All species showed a significant increase in the number of eggs parasitized with increasing egg density (Table 3 ). The functional responses of Trissolcus spp. to increasing densities of $E$. heros eggs are presented in Fig. 4. Graphic analysis and logistic regression indicate a type III functional response of the four species (Fig. 4, right side and Table 4). The analyses for the Trissolcus spp. show that linear parameters of the polynomial regression positives and significantly different from 0 and the quadratic parameter negatives (Table 4) Additionally, the curve of number of eggs parasitized (Fig. 4, left side) was steepest in the middle egg densities, resulting in the proportion of the eggs parasitized by the females of the four species reaching a maximum at these densities, further indicating a type III functional response (Hassel, 2000) (Fig. 4, right side). T. basalis showed the lowest attack coefficient (b) and handling time $\left(T_{\mathrm{h}}\right)$ of the four species, however this value was not significantly different with the values of $T$. teretis (Table 5), consequently $T$. basalis also showed the highest maximum attack rate ( $T / T_{\mathrm{h}}, 34.42$ eggs) followed by $T$. brochymenae and $T$. teretis, which showed similar values for this parameter $(25.58$
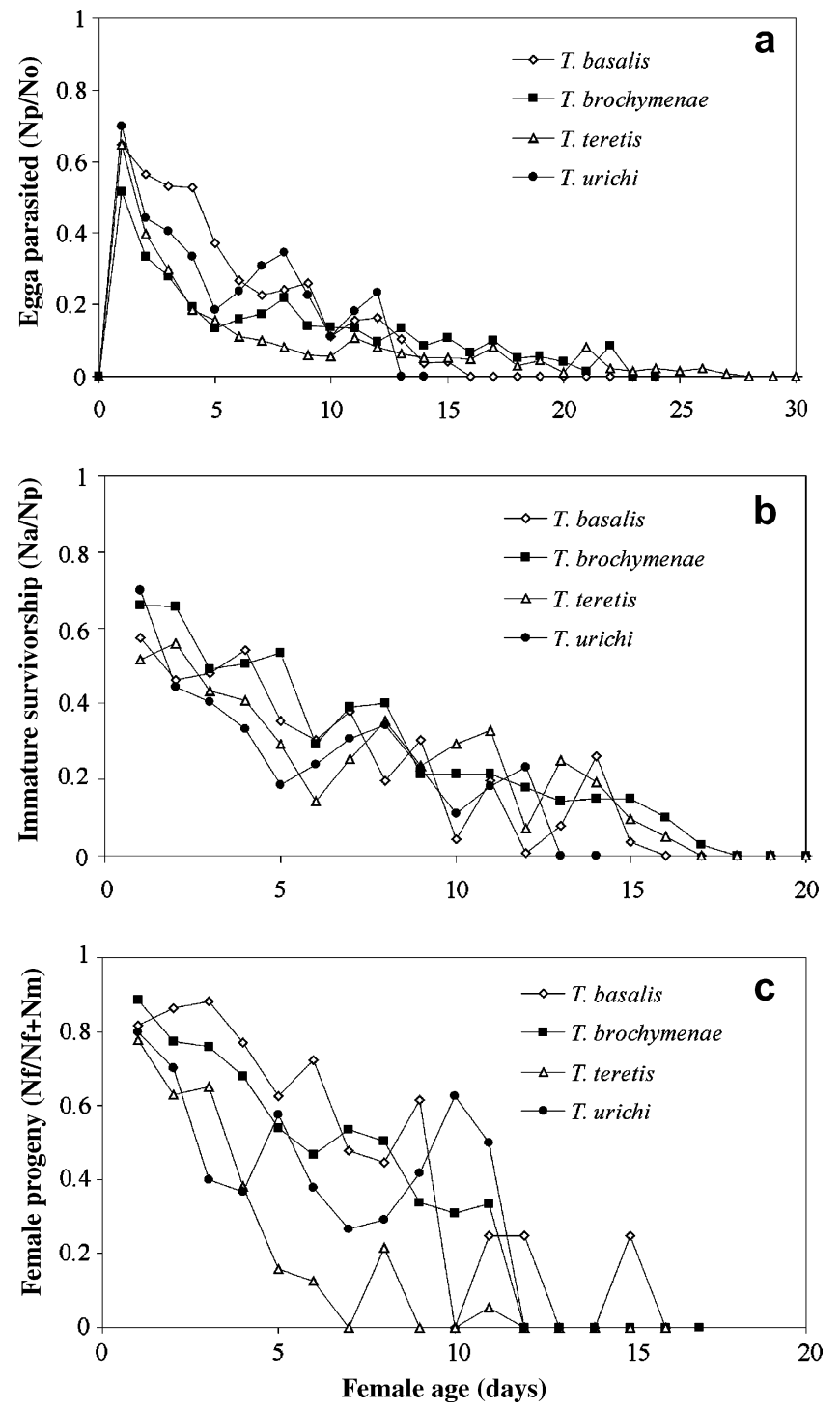

Fig. 3. Reproductive potential of Trissolcus spp. reared on Euschistus heros eggs. (a) Proportion of eggs parasitized in relation to female reproductive age. (b) Proportion of immature survival in relation to female reproductive age. (c) Sexual rate in relation to female reproductive age. $N_{\mathrm{p}}$, number of eggs parasitized; $N_{\mathrm{o}}$, number of eggs offered; $N_{\mathrm{a}}$, number of adults obtained from a egg mass; $N_{\mathrm{f}}$, number of females obtained from a egg mass; $N_{\mathrm{m}}$, number of males obtained from a egg mass.

and 25.03 eggs, respectively), and T. urichi (14.80 eggs) and this is responsible for the difference in asymptotes in the functional response observed for Trissolcus spp. (Fig. 4, left side).

Table 2

Fecundity table parameters, mean values (CL 95\%), estimates from LIFETABLE.SAS software for Trissolcus spp. using E. heros eggs as host

\begin{tabular}{lllll}
\hline Species & Ro & $r_{\mathrm{m}}$ & $T$ & $\lambda$ \\
\hline T. basalis & $78.39 \mathrm{a}(69.12-87.66)$ & $0.30 \mathrm{a}(0.28-0.32)$ & $14.54 \mathrm{a}(14.27-14.81)$ & $1.35 \mathrm{a}(1.33-1.37)$ \\
T. brochymenae & $43.06 \mathrm{~b}(33.79-52.34)$ & $0.33 \mathrm{bc}(0.31-0.35)$ & $11.51 \mathrm{~b}(11.24-11.78)$ & $1.39 \mathrm{bc}(1.37-1.41)$ \\
T. teretis & $31.40 \mathrm{~b}(22.13-40.67)$ & $0.31 \mathrm{ab}(0.29-0.33)$ & $11.09 \mathrm{c}(10.82-11.36)$ & $1.36 \mathrm{ab}(1.34-1.38)$ \\
T. urichi & $39.49 \mathrm{~b}(30.22-48.76)$ & $0.35 \mathrm{c}(0.33-0.36)$ & $10.59 \mathrm{~d}(10.32-10.86)$ & $1.41 \mathrm{c}(1.39-1.43)$ \\
\hline
\end{tabular}

Mean in each in columns followed by the same letter are not significantly different ( $t$ contrast, $P>0.05$ ). 


\section{Discussion}

The biology of Trissolcus spp. using E. heros eggs as hosts show differences between the species suggesting a substantial variation in the ability of different species to exploit resources from E. heros eggs. Immature survivorship was greater in T. basalis $(75 \%)$ than in other species. Development time of immature stages showed the opposite trend to survivorship, with $T$. urichi showing the fastest development, but lowest survivorship. Thus there could be a trade-off, where species that exploit the egg resource quickly do so with high mortality. The survivorship could be highly influenced by the species in which the larva develops, since Trissolcus spp. developing in different host eggs has different survivorship (Cividanes and Figueiredo, 1996; Kivan and Kilic, 2002, 2004; Torres et al., 2002).

Because four females were used for each egg mass superparasitism was not avoided completely. We believe this did not affect our experiments, because females guard the eggs they have parasitized for several hours (Field et al., 1998), and development times and survivorship calculated here are similar to those observed normally in our laboratory colonies and in the progeny from first egg masses offered to females maintained individually in this work (data not shown). Furthermore, the observed sex ratio in the progeny of this experiment was strongly female biased ( $T$. basalis $0.81 ; T$. brochymenae $0.88 ; T$. teretis 0.78 and $T$. urichi 0.79 all for females), which suggests no superparasitism, since this normally leads to a shift towards male biased sex ratio (Field et al. 1997).

Host species appear to have smaller influence in development time of $T$. basalis because this species showed here similar values to those reported previously when developing in N. viridula eggs (Awan et al., 1990; Corrêa-Ferreira and Moscardi, 1994). This contrasts with T. brochymenae, which had its development time influenced by its host (Torres et al., 1996-1997, 2002), revealing species-specific responses to alternative hosts.

The few life table studies on Trissolcus and Telenomus species that were done in environmental conditions similar to this work reported similar values to those presented here (Orr et al., 1986; Orr, 1988; Torres et al., 1996-1997; Chabi-Olaye et al., 2001; Kivan and Kilic, 2005). Longevity of $T$. basalis was below the longevity of this species when reared on N. viridula (Awan et al., 1990; Chabi-Olaye et al., 2001). Additionally, Awan et al (1990) found significantly higher male longevity. In $T$. brochymenae reared on Podisus nigrispinus, longevity of females (17.3 days, Torres et al., 2002) was proximal to mean longevity on E. heros, whereas in contrast mean male longevity on $P$. nigrispinus was lower (6.3 days, Torres et al., 2002).

The fecundity of $T$. basalis, which was estimated, in this work by the number of eggs parasitized, was higher than the other species, but the mean fecundity (112.5 eggs parasitized) was below of the mean fecundity of this species when attacking its main host, $N$. viridula (Powell and Shepard, 1982; Corrêa-Ferreira and Zamataro, 1989; Awan et al., 1990; Corrêa-Ferreira and Moscardi, 1994). T. brochymenae, T. teretis and T. urichi showed the same mean fecundity. Females of the four species studied showed a drop in fecundity and progeny survivorship with age. This may be a general characteristic of Telenominae, since it has been previously observed in $T$. basalis, $T$. simoni and in Telenomus spp. (Powell and Shepard, 1982; Orr et al., 1986; Corrêa-Ferreira and Zamataro, 1989; Awan et al., 1990; Corrêa-Ferreira and Moscardi, 1994; Pacheco and Corrêa-Ferreira, 1998; Kivan and Kilic, 2005).

There are no data on E. heros life table parameters, so assessment of relative reproductive parameters in order to establish Trissolcus spp. potential as biological control agents is difficult. Data of reproductive potential, under laboratory conditions, showed that E. heros females can oviposit approximately 130 eggs in their life with an estimated progeny of 40 females/female (Costa et al., 1998; Malaguido and Panizii, 1999). T. basalis, T. brochymenae and $T$. urichi showed a production of female progeny (net reproductive rate, Ro), higher or similar to E. heros, and generation time $(T)$ was approximately half of that observed in laboratory colonies of E. heros (approximately 40 days, R.A. Laumann, pers. observation). Based on these observations, the species of Trissolcus studied in this work have the potential for faster population increase than the stink bug.

The relationship between host density and number parasitized was shown to have a sigmoidal function (type III functional response) for all Trissolcus species studied here.

Table 3

Results from two-way ANOVA comparing number of egg parasited by Trissolcus spp. offered in different densities and results from ANOVA for number of egg parasited in different densities for each species

\begin{tabular}{|c|c|c|c|c|}
\hline Source of variation & $\mathrm{df}$ & MS & $F$ & $P$ \\
\hline \multicolumn{5}{|l|}{ Two-way ANOVA } \\
\hline Host density & $9-160$ & 1652.42 & 116.09 & $<0.001$ \\
\hline Parasitoid species & $3-160$ & 222.94 & 15.66 & $<0.001$ \\
\hline \multicolumn{5}{|l|}{ ANOVA for individual species } \\
\hline T. basalis & $9-40$ & 646.26 & 43.90 & $<0.001$ \\
\hline T. brochymenae & $9-40$ & 518.28 & 124.48 & $<0.001$ \\
\hline
\end{tabular}



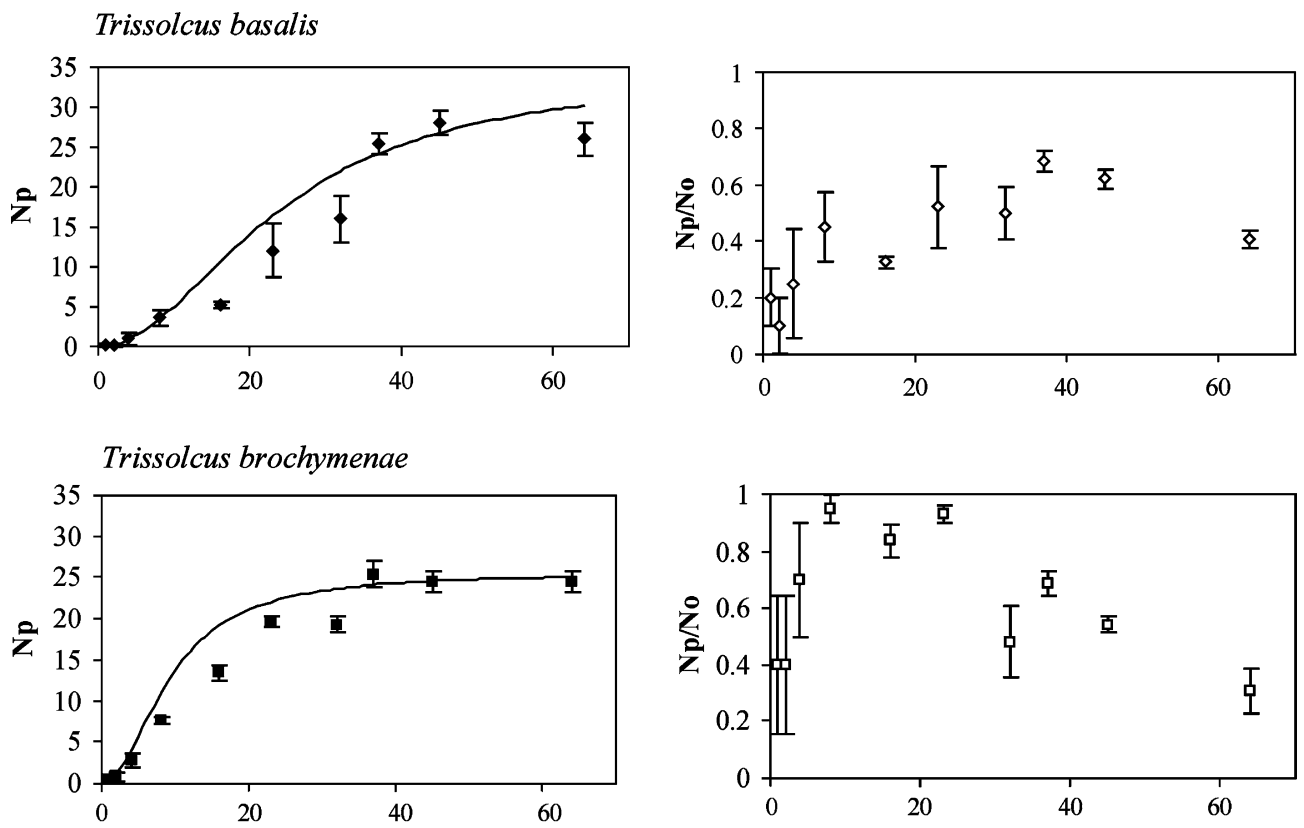

Trissolcus teretis
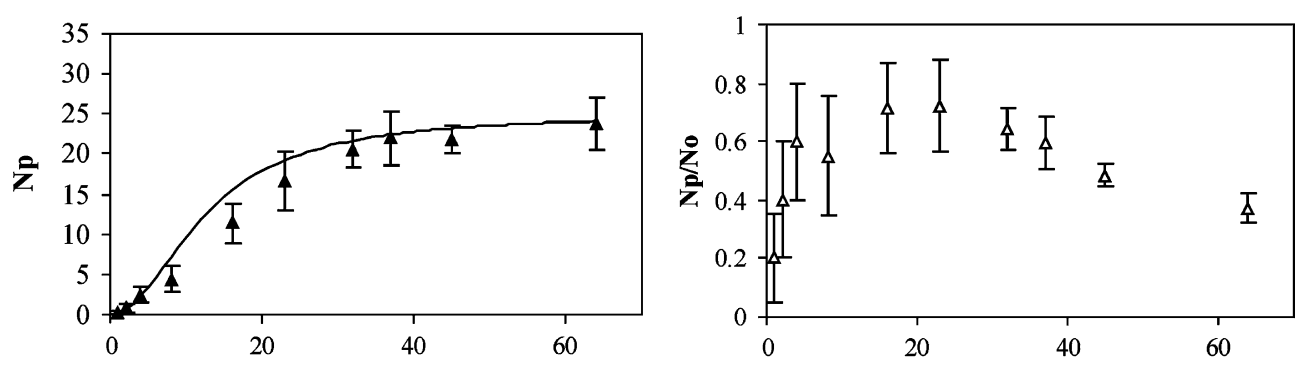

Trissolcus urichi
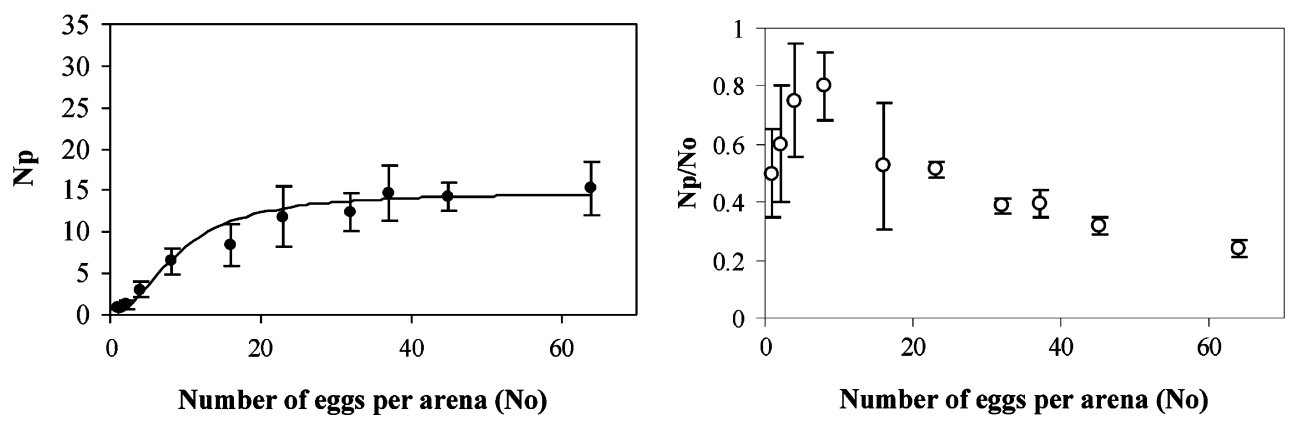

Fig. 4. Components of functional response of Trissolcus spp. Left: Number of egg parasitized $\left(N_{\mathrm{p}}\right)$ vs. Number of eggs in arenas ( $\left.N_{\mathrm{o}}\right)$. Right: Proportion of $E$. heros eggs parasitized $\left(N_{\mathrm{p}} / N_{\mathrm{o}}\right)$ vs. Number of eggs in arenas $\left(N_{\mathrm{o}}\right)$. Ticks represent mean values from five repetition in each host density. $N_{\mathrm{p}}$ : number of egg parasitized. Lines in left side figures are the predicted values for the functional response.

These results are promising, since this type of response can cause density-dependent parasitism (Fig. 4), which could lead to more efficient population regulation (Holling, 1959; Bernstein, 2000). These results agree with the functional responses found for Trissolcus grandis and Trissolcus semistriatus, that were also type III on their preferred hosts. In these species the functional response is influenced by plants and host species (Fathipour et al., 2001; Asgari et al., 2002; Allahyari et al., 2004). Type III responses are less common than type II responses (Mills and Lacan,
2004), but seem to be common in Trissolcus species. More studies are necessary in order to establish general patterns.

The species of Trissolcus evaluated in this work are potentially effective as natural enemies of $E$. heros, as previously suggested generally for scelionid wasps (Orr, 1988), and demonstrated in the biological control of $N$. viridula with T. basalis (Cumber, 1951; Caltagirone, 1981; Clarke, 1990; Clarke and Walter, 1995; Colazza and Bin, 1995; Corrêa-Ferreira and Moscardi, 1995). Management of stink bugs in soybean with $T$. basalis in Brazil has proved 
Table 4

Logistic regression analyses of the proportion of E. heros eggs parasited by Trissolcus spp. in relation to initial egg number

\begin{tabular}{|c|c|c|c|c|c|}
\hline Species & Parameter & Estimate & SE & $\chi^{2}$ & $P$ \\
\hline \multirow[t]{3}{*}{ T. basalis } & $P_{0}($ constant $)$ & -5.492 & 2.063 & 7.09 & 0.0078 \\
\hline & $P_{1}$ (linear) & 2.603 & 1.071 & 5.91 & 0.0151 \\
\hline & $P_{2}$ (quadratic) & -0.487 & 0.197 & 6.11 & 0.0135 \\
\hline \multirow[t]{3}{*}{ T brochymenae } & $P_{0}($ constant $)$ & 0.422 & 0.423 & 0.99 & 0.3191 \\
\hline & $P_{1}$ (linear) & 0.158 & 0.049 & 10.40 & 0.0013 \\
\hline & $P_{2}$ (quadratic) & -0.006 & 0.002 & 14.69 & 0.0001 \\
\hline \multirow[t]{3}{*}{ T. teretis } & $P_{0}($ constant $)$ & -0.685 & 0.387 & 3.14 & 0.0766 \\
\hline & $P_{1}$ (linear) & 0.178 & 0.004 & 15.85 & $<.0001$ \\
\hline & $P_{2}$ (quadratic) & -0.006 & 0.001 & 16.12 & $<.0001$ \\
\hline \multirow[t]{3}{*}{ T. urichi } & $P_{0}($ constant $)$ & -0.597 & 0.738 & 0.65 & 0.4184 \\
\hline & $P_{1}$ (linear) & 0.539 & 0.240 & 5.03 & 0.0249 \\
\hline & $P_{2}$ (quadratic) & -0.056 & 0.023 & 5.75 & 0.0165 \\
\hline
\end{tabular}

Table 5

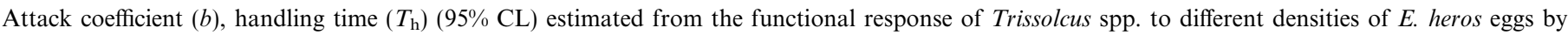
CATMOD procedure (Juliano, 1993)

\begin{tabular}{|c|c|c|c|}
\hline Species & $b\left(\mathrm{~h}^{-1}\right)$ & $T_{\mathrm{h}}(\mathrm{h} / \mathrm{egg})$ & $F_{2,48}-P$ \\
\hline T. basalis & 0.0099 a $(0.0057-0.0142)$ & 0.1743 a $(0.1397-0.2088)$ & $339.72-P<0.001$ \\
\hline T. brochymenae & 0.0499 b $(0.0285-0.0714)$ & 0.2346 b $(0.2195-0.2496)$ & $1272.13-P<0.001$ \\
\hline T. teretis & $0.0264 \mathrm{ab}(0.0078-0.0450)$ & $0.2397 \mathrm{ab}(0.2033-0.2762)$ & $267.63-P<0.001$ \\
\hline T. urichi & $0.0304 \mathrm{ab}(0.0065-0.0543)$ & 0.4053 с $(0.3534-0.4572)$ & $248.45-P<0.001$ \\
\hline
\end{tabular}

that augmentative liberations are an efficient technique (Corrêa-Ferreira and Moscardi, 1996; Corrêa-Ferreira, 2002) especially to control $N$. viridula populations. For management of $E$. heros, $T$. basalis showed lower efficiency, but was still reasonable, with a $45 \%$ population reduction (Corrêa-Ferreira and Moscardi, 1996). Additionally, in this region $E$. heros is the species with the highest parasitism indices on soybean (Corrêa-Ferreira, 2002).

To date, only the combination of $T$. podisi with $T$. basalis has been used for stink bug management (Corrêa-Ferreira, 2002), and a multi-species use of Scelionidae, in natural, restructured or synthetic guilds, as has been suggest by Ehler (2000), can be an efficient stink bug management tactic. Results of this work show that Trissolcus spp. from central Brazil have the potential to be included in this approach. However, caution must be taken to avoid interference competition as was demonstrated for $T$. basalis and T. urichi in the laboratory (Sujii et al., 2002).

Additionally, functional responses recorded from single females foraging in isolation can be modified when other parasitoids are foraging in the same patch, and a type III functional response can change to type II (Montoya et al., 2000). Furthermore in field environments, parasitoids are not confined to a single patch, and this betweenpatch movement can affect the density-dependence observed (Hassel, 2000). Thus, for multiple introductions or liberations, total host mortality in species combinations need to be assessed before assuming that introducing several species with a type III response will still cause density-dependent parasitism.

Stiling and Cornelissen (2005) recently showed that the use of several natural enemy species can lead to better results than single species approaches. Trissolcus species are oligophagous or polyphagous (Orr, 1988; Austin et al., 2005) and this is another attribute that can contribute to their potential for stink bug control (Stiling and Cornelissen, 2005). However, alternative hosts can potentially have negative, positive or neutral effects on target prey predation (Harmon and Andow, 2004), and complex indirect effects can sometimes not be predicted from biology or behavioral mechanisms of isolated parasitoid or predator species (Cardinale et al., 2003), indicating that specific studies with the target community need to be carried out prior to establishing any management tactics (Sujii et al, 2002). Surveys of naturally parasitized $E$. heros eggs, in central Brazil, showed that coexistence of Trissolcus spp. and Telenomus podisi can be possible (Medeiros et al., 1997).

Stink bugs are serious pests of many major food crops (Panizzi, 1997) and in recent years, have adapted to new crops such as cotton (Willich et al., 2004a, b, c; Willrich Siebert et al., 2005), maize (Townsend and Sedlacek, 1986; Ávila and Panizzi, 1995) and sunflower (Panizzi and Machado-Neto, 1992; Malaguido and Panizii, 1999). The laboratory results presented here suggest that Trissolcus species have biological attributes and behavioral responses to host density that could lead to density-dependent parasitism and efficient local regulation of stink bug populations. Further work is needed to understand how parasitism by scelionid wasps will vary in more complex environments, as would occur in multiple-species introductions or when alternative hosts are present. This information could lead to establishing effective biocontrol strategies that contribute to solving current and future stink bug pests problems. 


\section{Acknowledgments}

The authors thank Hélio Moreira dos Santos and Diva Tiburcio for helping with laboratory rearing of the insects used in this study. The authors thank to Dr. George Heimpel and two anonymous reviewers for their critical comments on earlier version of the manuscript and Dr. Michael Birkett (Rothamsted Research, UK) for insightful comments and English revision. This investigation was supported by Brazilian Council for Scientific and Technological Development (CNPq), Embrapa-Recursos Genéticos e Biotecnologia and Distrito Federal Research Foundation (FAP-DF).

\section{References}

Allahyari, H., Fard, P.A., Nazari, J., 2004. Effects of host on functional response of offspring in two populations of Trissolcus grandis on the sunn pest. Journal of Applied Entomology 128, 39-43.

Asgari, S., Sahragard, A., Kamali, K., Soleimannejadian, E., Fathipour, Y., 2002. Functional and numerical responses of sunn pest egg parasitoid, Trissolcus semistriatus, reared on Eurygaster integriceps and Graphosoma lineatum. Applied Entomology and Phytopatology 69, 97-110.

Austin, A.D., Johnson, N.F., Dowton, M., 2005. Systematic, evolution and biology of scelionid and platygastrid wasps. Annual Review of Entomolgy 50, 553-582.

Ávila, C.J., Panizzi, A.R., 1995. Ocurrence and damage by Dichelops (Neodichelops) melacanthus (Dallas) (Heteroptera: Pentatomidae) on corn. Annais da Sociedade Entomologica do Brasil 24, 193-194.

Awan, M.S., Wilson, L.T., Hoffmann, M.P., 1990. Comparative biology of three geographic populations of Trissolcus basalis (Hymenoptera: Scelionidae). Environmental Entomology 19, 387-392.

Bernstein, C., 2000. Host-parasitoid models: the story of successful failure. In: Hochberg, M., Ives, A. (Eds.), Population Biology of HostParasitoids Interactions. Princeton University Press, Princeton, New Jersey, pp. 41-57.

Boethel, D.J., Russin, J.S., Wier, A.T., Layton, M.B., Mink, J.S., Boyd, M.L., 2000. Delayed maturity associated with southern green stink bug (Heteroptera: Pentatomidae) injury at various soybean phenological stages. Journal of Economic Entomology 93, 707-712.

Borges, M., Costa, M.L.M., Sujii, E.R., Cavalcanti, M.G., Redigolo, G.F., Resck, I.S., Vilela, E.F., 1999. Semiochemical and physical stimuliiInvolved in host recognition by Telenomus podisi (Hymenoptera: Scelionidae) toward Euschistus heros (Heteropter: Pentatomidae). Physiological Entomology 24, 227-233.

Borges, M., Colazza, S., Ramirez-Lucas, P., Chauhan, K.R., Moraes, M.C.B., Aldrich, J.R., 2003. Kairomonal effect of walking traces from Euschistus heros (Heteroptera: Pentatomidae) on two strains of Telenomus podisi (Hymenoptera: Scelionidae). Physiological Entomology 28, 349-356.

Caltagirone, L.E., 1981. Landmark examples in classical biological control. Annual Review of Entomology 26, 213-232.

Cardinale, B.J., Harvey, C.T., Gross, K., Ives, A.R., 2003. Biodiversity and biocontrol: emergent impacts of a multi-enemy assemblage on pest suppression and crop yield in an agroecosystem. Ecological Letters 6, $857-865$.

Cavalcante, C., Moraes, M.C.B., Laumann, R.A., Borges, M., 2006. Sensory response of the egg parasitold Telenomus podisi to stimuli from the bug Euschistus heros. Pesquisa Agropecuaria Brasilera 41, 1093-1098.

Clarke, A.R., 1990. The control of Nezara viridual L. with introduced egg parasitoids in Australia: a review of a landmark example of classical biological control. Australian Journal of Agricultural Research 41, $1127-1146$
Clarke, A.R., Walter, G.H., 1995. "Strains" and the classical biological control of insects pests. Canadian Journal of Zoology 73, 1777-1790.

Chabi-Olaye, A., Schulthess, F., Poehling, H.M., Borgmeister, C., 2001. Factors affectin the biology of Telenomus isis (Polaszek) (Hymenoptera: Scelionidae) an egg parasitid of cereal stem borers in West Africa. Biological Control 21, 4-54.

Cividanes, F.J., Figueiredo, J.G., 1996. Desenvolvimento e emergência de Trissolcus brochymenae (Ashmead) e Telenomus podisi Ashmead (Hymenoptera: Scelionidae) em diferentes temperaturas. Annais da Sociedade Entomológica do Brasil 25, 207-211.

Colazza, S., Bin, F., 1995. Efficiency of Trissolcus basalis (Hymenoptera: Scelionidae) as an egg parasitoid of Nezara viridula (Heteroptera: Pentatomidae) in central Italy. Environmental Entomology 24, $1703-$ 1707.

Corrêa-Ferreira, B.S., 2002. Trissolcus basalis para o controle de percevejos da soja. In: Parra, J.R.P., Botelho, P.S., Corrêa-Ferreira, B., Bento, J.M.S. (Eds.), Controle Biológico no Brasil. Parasitóides e Preadores, Manole Ltda., São Paulo, pp. 449-476.

Corrêa-Ferreira, B.S., Zamataro, C.E.O., 1989. Capacidade reprodutiva e longevidade dos parasitóides de ovos Trissolcus basalis (Wollaston) e Trissolcus mitsukurii Ashmead (Hymenoptera: Scelionidae). Revista Brasileira de Biolologia 49, 621-626.

Corrêa-Ferreira, B.S., Moscardi, F., 1994. Temperature effect on the biology and reproductive perfomance or the egg parasitoid Trissolcus basalis (Woll.). Annais da Sociedade Entomologica do Brasil 23, 399 408.

Corrêa-Ferreira, B.S., Moscardi, F., 1995. Seasonal occurrence and host spectrum of egg parasitoids associated with soybean stink bugs. Biological Control 5, 196-202.

Corrêa-Ferreira, B.S., Moscardi, F., 1996. Biological control f soybean stink bugs by inocluative releases of Trissolcus basalis. Entomologia Experimentalis et Applicata 79, 1-7.

Costa, M.L.M., Borges, M., Vilela, E.F., 1998. Biologia reprodutiva de Euschistus heros (F.) (Heteroptera: Pentatomidae). Annais da Sociedade Entomologica do Brasil 27, 559-568.

Crouzel, I.S., Saini, E.D., 1983. Importancia de Trissolcus basalis (Wollaston) (Hymenoptera: Scelionidae) en la Argentina para el control biológico de Nezara viridula (L.) (Hem.: Pentatomidae). Revista da Sociedade Entomologica Argentina 42, 257-260.

Cumber, C.J., 1951. The introduction into New Zealand of Microphanurus basalis Wool. (Hymenotpera: Scelionidae), egg parasite of the green vegetable bug Nezara viridula L. (Pentatomidae). New Zealand Journal of Science and Technology Section B 32, 30-37.

Ehler, L.E., 2000. Farmscape ecology of stink bugs in Northern California. Thomas Say Publications in Entomology, Entomological Society of America, Maryland, USA, 59pp.

Ehler, L.E., 2002. An evaluation of some natural enemies of Nezara viridula in northern California. Biocontrol 47, 309-325.

Fathipour, Y., Kamali, K., Khalghami, J., Abdollahi, G., 2001. Functional response of Trissolcus grandis (Hym., Scelionidae) on different egg densities of Eurygaster integriceps (Het., Scutellereidae) and effects of different wheat genotypes on it. Applied Entomology and Phytopathology 68, 123-136.

Field, S.A., Keller, M.A., Calbert, G., 1997. The pay-off from superparasitism in the egg parasitoid Trissolcus basalis, in relation to patch defense. Ecological Entomology 22, 4142-4149.

Field, S.A., Calbert, G., Keller, M.A., 1998. Patch defence in the parasitoid wasp Trissolcus basalis (Insecta: Scelionidae): the time structure of pairwise contests, and the "waiting game". Ethology 104, 821-840.

Hassel, M.P., 2000. The spatial and temporal dynamics of host-parasitoid interactions. Oxford Series in Ecology and Evolution, Oxford, UK, 198pp.

Holling, C.S., 1959. The components of predation as revealed by a study of small mammal predation of the European sawfly. Canadian Entomology 91, 293-320.

Harmon, J.P., Andow, D.A., 2004. Indirect effects between shared prey: predictions for biological control. Biocontrol 49, 605-626. 
Hoffmann, M.P., Davison, N.A., Wilson, L.T., Ehler, L.E., Jones, W.A., Zalom, F.G., 1991. Imported wasp helps control southern green stink bug. California Agriculture 45 (3), 20-22.

Johnson, M.T., Follet, P.A., Taylor, A.D., Jones, V.P., 2005. Impacts of biological control and invasive species on a non-traget native Hawaiian insect. Oecologia 142, 529-540.

Juliano, S.A., 1993. Nonlinear curve fitting: predation and functional response curves. In: Schneider, S.M., Gurevitch, J. (Eds.), Design and Analysis of Ecological Experiments. Chapman and Hall, New York, pp. 159-182.

Kivan, M., Kilic, N., 2002. Host preference: parasitism, emergence and development of Trissolcus semistriatus (Hym., Scelionidae) in various host eggs. Journal of Applied Entomology 126, 395-399.

Kivan, M., Kilic, N., 2004. Parastiism and development of Trissolcus simoni in eggs of different host species. Phytoparasitica 32, 57-60.

Kivan, M., Kilic, N., 2005. Effects of temperature on reproductive capacity and longevity of Trissolcus simoni, an egg parasitoid of Eurygaster integriceps. Journal of Pesticide Science 78, 105-108.

Kobayashi, T., Cosenza, G.W., 1987. Integrated control of soybean stink bugs in the cerrados. Japanese Agricultural Research Quarterly 20, 229 236.

Maia, A.H.N., Luiz, A.J.B., Campanhola, C., 2000. Statistical inference on associated fertility life table parameters using jackknife technique: computational aspects. Journal of Economic Entomology 93, 511-518.

Malaguido, A.B., Panizii, A.R., 1999. Nymph and adult biology of Euschistus heros (Hemiptera: Pentatomidae) and its abundance related to planting date and phenological stages of sunflower. Annals of the Entomological Society of America 92, 424-429.

Medeiros, M.A., Schmidt, F.V.G., Loiácono, M.S., Carvalho, V., Borges, M., 1997. Parasitismo e predação em ovos de Euschistus heros (Fab.) (Heteroptera: Pentatomidae) no Distrito Federal, Brasil. Annais da Sociedade Entomologica do Brasil 26, 397-401.

Medeiros, M.A., Loiácono, M.S., Borges, M., Schmidat, F.V.G., 1998. Incidência natural de parasitóides em ovos de percevejos (Hemíptera; Pentatomidae) encontrados na soja no distrito Federal. Pesquisa Agropecuraia Brasileira 33, 1431-1435.

Mills, N.J., 2001. Factors influencing top-down control of insect pest populations in biological control systems. Basical and Applied Ecology 2, 323-332.

Mills, N.J., Lacan, I., 2004. Ratio dependence in the functional response of insect parasitoids: evidence from Trichogramma minutum foraging for eggs in small patches. Ecological Entomology 29, 208-216.

Montoya, P., Liedo, P., Benrey, B., Barrera, J.F., Cancino, J., Aluja, M., 2000. Functional response and superparasitism by Diachasmimorpha longicaudata (Hymenoptera: Braconidae), a parasitoid of fruit flies (Diptera: Tephritidae. Annals of the Entomological Society of América $93,47-54$

Moraes, M.C.B., Laumann, R.A., Sujii, E.R., Pires, C.S.S., Borges, M., 2005. Induced volatiles in soybean and pigeon pea plants artificially infested with the Neotropical brown stink bug, Euschistus heros, and their effect on the egg parasitoid, Telenomus podisi. Entomologia Experimentalis et Applicata 115, 227-237.

Orr, D.B., Russin, J.S., Boethel, D.J., 1986. biology and behavior of Telenomus calvus (Hymenoptera; Scelionidae) a phoretic egg parasitoid of Podisus maculiventris (Hemiptera: Pentatomidae). Canadian Entomology 118, 1063-1072.

Orr, D.B., 1988. Scelionid wasps as biological control agents: a review. Florida Entomologist 71, 506-528.

Pacheco, D.J.P., Corrêa-Ferreira, B.S.S., 1998. Reproductive pontential and longevity of the parasitoid Telenomus podisi Ashmead in eggs of different stink bugs species. Annais da Sociedade Entomologica do Brasil 27, 585-591.

Panizzi, A.R., 1997. Wild hosts of pentatomids: ecological significance and role in their pest status crops. Annual Review of Entomology 42, 99-122.
Panizzi, A.R., Slansky, F., 1985. Review of phytophagous pentatomids (Hemiptera: Pentatomidae) associated with soybean in the Americas. Florida Entomologist 68, 184-214.

Panizzi, A.R., Machado-Neto, E., 1992. Development of nymphs and feeding habits of nymphal and adult Edessa meditabunda (Heteroptera: Pentatomidae) on soybean and sunflower. Annals of the Entomological Society of América 85, 477-481.

Panizzi, A.R., Corrêa-Ferreira, B.S.S., 1997. Dynamics in the insect fauna adaptation to soybean in the tropics. Trends on Entomology 1, 72-88.

Powell, J.E., Shepard, M., 1982. Biology of Australian and United States strains of Trissolcus basalis, a parasitoid of the green vegetable bug, Nezara viridula. Australian Journal of Ecology 7, 181-186.

Rogers, D.J., 1972. Random search and insect population models. Journal of Animal Ecology 41, 369-383.

SAS Institute Inc., 1990. SAS language: reference, version 6. fourth ed. SAS Institute, Cary.

Sosa-Gómez, D.R., Moscardi, F., 1995. Retenção foliar diferencial em soja provocada por percevejos (Heteroptera: Pentatomidae). Annais da Sociedade Entomologica do Brasil 24, 401-404.

Stiling, P., Cornelissen, T., 2005. What makes a successful biocontrol agent? A meta-analysis of biological control agent performance. Biological Control 34, 236-246.

Sujii, E.R., Costa, M.L.M., Pires, C.S., Colazza, S., Borges, M., 2002. Inter and intra-guild interactions in egg parasitoid species of the soybean stink bug complex. Pesquisa Agropecuária Brasileira 37, 1541-1549.

Torres, J.B., Zanuncio, J.C., Picanço, M.C., Oliveira, A.C., 1996-1997. Parámteros poblacionales de tres parasitóides (Hymenoptera: Scelionidae, Encyrtidae) utilizando al depredador Podisus nigrispinus (Hemíptera; Pentatomidae) como hospedero. Revista de Biologia Tropical 40, 233-240.

Torres, J.B., Musolin, D.L., Zanuncio, J.C., 2002. Thermal requeriments and parasitism capacity of Trissolcus brochymenae (Ashmead) (Hymenotpera: Scelionidae) under constant and fluctuating temperatures, and assessment of development in field conditions. Biocontrol Science and Technology 12, 583-593.

Townsend, L.H., Sedlacek, J.D., 1986. Damage to corn caused by Euschistus servus, E. variolarius and Acrosternum hilare (Heteroptera: Pentatomidae) under greenhouse conditions. Journal of Economic Entomology 79, 1254-1258.

Trexler, J.C., Charles, E.M., Travis, J., 1988. How can the functional response best be determined? Oecologia 76, 206-214.

Villas-Bôas, G.L., Gazzoni, D.L., Oliveira, M.C.N. de, Pereira, N.P., Roessing, A.C., França Neto, J.B., Henning, A., 1990. Efeito de diferentes populações de percevejos sobre o rendimento e seus componentes, características agronômicas e qualidade de sementes de soja. Boletim Pesquisa, N. 1. Embrapa-CNPSo (Ed.), Londrina, $43 \mathrm{p}$.

Willrich, M.M., Leonard, B.R., Padgett, G.B., 2004a. Influence of southern green stink bug, Nezara viridula L., on late-season yield losses in cotton, Gossypium hirsutum L. Environmental Entomology 33, 1095-1101.

Willrich, M.M., Leonard, B.R., Gable, R.H., Lamotte, L.R., 2004b. Boll injury and yield losses in cotton associated with brown stink bug (Heteroptera: Pentatomidae) during flowering. Journal of Economic Entomology 97, 1928-1934.

Willrich, M.M., Leonard, B.R., Temple, J., 2004c. Injury to preflowering and flowering cotton by brown stink bug and southern green stink bug. Journal of Economic Entomology 97, 924-933.

Willrich Siebert, M.M., Leonard, B.R., Gable, R.H., Lamotte, L.R., 2005. Cotton boll age influences feeding preference by brown stink bug (Heteroptera: Pentatomidae). Journal of Economic Entomology 98, 82-87. 